\section{Abrupt Shifts in Horn of Africa Hydroclimate Since the Last Glacial Maximum}

\author{
Jessica E. Tierney, ${ }^{1 \star}$ Peter B. deMenocal ${ }^{2}$ \\ ${ }^{1}$ Woods Hole Oceanographic Institution, 266 Woods Hole Road, Woods Hole, MA 02540, USA. ${ }^{2}$ Lamont \\ Doherty Earth Observatory, Palisades, NY 10964, USA. \\ ${ }^{*}$ Corresponding author. E-mail: tierney@whoi.edu
}

The timing and abruptness of the initiation and termination of the Early Holocene African Humid Period are a subject of ongoing debate, with direct consequences for our understanding of abrupt climate change, paleoenvironments, and early human cultural development. Here we provide proxy evidence from the Horn of Africa region that documents abrupt transitions into and out of the African Humid Period in northeast Africa. Similar and generally synchronous abrupt transitions at other East African sites suggest that rapid shifts in hydroclimate are a regionally coherent feature. Our analysis suggests that the termination of the African Humid Period in the Horn of Africa occurred within centuries, underscoring the non-linearity of the region's hydroclimate.

During the Early Holocene epoch between roughly 11-5 ka BP, the presently hyperarid Saharan desert was dotted with large and small lakes, savannah grasslands, and, in some regions, humid tropical forests and shrubs $(1,2)$. This "African Humid Period (AHP)" was a unique hydrological regime and has been a focal point of African paleoclimate studies, both for its climatological implications $(3,4)$ and its influence on the emergence of pharaonic civilization along the Nile $(5,6)$. The fundamental cause of the AHP - dramatic increases in summer precipitation triggered by orbital forcing of African monsoonal climate and amplified by oceanic and terrestrial feedbacks - is well understood $(7,8)$. However, the abruptness with which the AHP began and, most particularly, ended is still debated. Dust proxy data from the west coast of Africa indicate a rapid, century-scale termination of the AHP near $5 \mathrm{ka}$ (9). In contrast, isotopic proxies from central Africa $(10,11)$ and pollen and sedimentological data from a lake in the eastern Sahara $(12,13)$ suggest a more gradual reduction in rainfall during the mid-Holocene following the orbital decline in boreal summer insolation. The discrepancy remains unresolved. Previous studies have attributed the difference in climate response to differing proxy sensitivities; e.g., dust may respond nonlinearly to a gradual drying of the Sahara (14), and conversely, pollen data may be smoothed due to mixed contributions from distal terrains (2). Alternatively, there may be regional heterogeneity in both the timing and duration of the AHP termination, reflecting the variable sensitivity of different regions to certain feedback mechanisms (in particular, vegetation feedbacks) $(3,4,6,15,16)$.

East Africa and the Arabian Peninsula also experienced humid conditions during the Early Holocene $(17,18)$. Speleothem $\delta^{18} \mathrm{O}$ data from southern Oman (Qunf Cave) and dust strontium isotopes off of Somalia suggest a gradual attenuation of humid conditions during the Holocene, much like the eastern Saharan pollen data $(19,20)$. These observations have led to the suggestion that the eastern Sahara and northeast Africa experienced a gradual end to the AHP $(3,4,12,15,21)$ and that abrupt responses were therefore limited to the western Sahara.

Here, we revisit the timing and abruptness of transitions into and out of the AHP in northeast Africa using a new record of hydroclimate from a key, yet previously understudied, region: the Horn of Africa. This record is derived from a marine core (P178-15P) located in the Gulf of
Aden (Fig. 1). The Gulf of Aden receives substantial amounts of terrestrial material during the summer monsoon season, when prevailing southwesterly winds transport dust from the Horn (Fig. 1 and fig. S1). Therefore, the terrestrial components (including organic matter) in the sediments predominantly reflect conditions in the Horn and Afar regions (see Supplementary Material). Twenty radiocarbon dates constrain the chronology of P178-15P and indicate an average sedimentation rate of 32 $\mathrm{cm} / \mathrm{ka}$ (see Supplementary Material)

We employ the hydrogen isotopic composition of leaf waxes $\left(\delta \mathrm{D}_{\text {wax }}\right)$ as a proxy for aridity, and more generally speaking, hydroclimate, including precipitation/evaporation balance and $\frac{m}{\sigma}$ changes in regional convection. $\delta \mathrm{D}_{\text {wax }} \stackrel{\mathrm{N}}{\mathbf{N}}$ has been widely used in African paleoclimate and is an effective indicator of changes in the isotopic composition of precipitation $\left(\delta \mathrm{D}_{P}\right)$ and aridity, with enriched isotopic values corresponding to drier conditions and depleted values to wetter conditions $(10,22)$.

More generally, tropical water isotopes are good tracers of large-scale changes in atmospheric circulation $(18,23)$ and therefore reflect regional, rather than local, shifts in the hydrological cycle. As Congo basin moisture is effectively blocked by the Ethiopian highlands and the Horn of Africa receives the majority of its rainfall from the Indian Ocean (24), we interpret the $\delta \mathrm{D}_{\text {wax }}$ values to primarily represent changes in western Indian Ocean hydroclimate.

The $\delta \mathrm{D}_{\text {wax }}$ record from the Gulf of Aden indicates that Horn of Africa hydroclimate has changed dramatically during the last 40,000 years (Fig. 2). Following the arid conditions of the Last Glacial Maximum (26$19 \mathrm{ka}$ ), the Horn region experienced a severe dry period coincident with the North Atlantic cooling event, Heinrich Event 1 (H1) (Fig. 2), consistent with previous proxy (25) and model (23) evidence from the AfroAsian monsoon domain. Following H1, there was a rapid transition to intermediate conditions coincident with the Bölling-Allerød (B/A) period and then a reversal into dry conditions during the Younger Dryas (YD), another North Atlantic cold event (Fig. 2). Upon the termination of the YD, the Horn of Africa rapidly moved into the most humid conditions of the past $40 \mathrm{ka}$, coincident with the AHP (Fig. 2). These conditions persisted until ca. $5 \mathrm{ka}$.

The $\delta \mathrm{D}_{\text {wax }}$ record from the Gulf of Aden is dominated by abrupt transitions that occur more rapidly than would be predicted from orbital forcing alone (Fig. 3). Two other $\delta \mathrm{D}_{\text {wax }}$ records from East Africa, from Lake Tanganyika (22) and Lake Challa (26), show similar and generally coeval abrupt transitions at the end of $\mathrm{H} 1$, the YD, and the AHP, even though these sites sit ca. $2000 \mathrm{~km}$ to south of the Gulf of Aden (Figs. 1 and 3). The overall similarity between the three records attests to the ability of water isotope proxies, specifically $\delta \mathrm{D}_{\text {wax }}$, to record large-scale hydroclimatic patterns in tropical Africa.

The perceived timing and abruptness of the transitions in each $\delta \mathrm{D}_{\text {wax }}$ record is subject to dating uncertainties as well as sedimentary properties. Therefore, we used a Monte Carlo method (27) to create empirical probability distributions for the midpoint and duration of each identified transition and more clearly assess the duration and synchronicity of these key climate transitions. (see Supplementary Information). We use these distributions to assess the timing of the transitions in a statistical fashion, 
by applying a $T$-test for contemporaneity (28) to test against the null hypothesis that the transitions are synchronous between two sites, or a $\chi^{2}$-test to test against the null hypothesis that the transitions at all three sites derive from the same mean, and are therefore likely synchronous. In both cases, we accept the null hypothesis if $p>0.05$.

Several noteworthy findings emerge from this analysis. First, we find that the termination of $\mathrm{H} 1$ and the YD are not likely synchronous at all sites. All age model iterations indicate an older timing for the H1-B/A transition at Lake Tanganyika than at the Gulf of Aden site (note that Lake Challa does not have a detectable H1 termination; see Supplementary Information). The median date of the transition in the Gulf of Aden record $(14,680 \mathrm{yr} \mathrm{BP})$ is close to the generally accepted timing of 14,700 yr BP (29) whereas the transition at Lake Tanganyika occurs nearly 1000 years earlier $($ median $=15,760 \mathrm{yr}$ BP). For the Challa and Tanganyika sites, the termination of the YD is likely synchronous $(T$-Test $p=0.99)$ and the timing (median of both $=11,600 \mathrm{yr} \mathrm{BP}$ ) is in good agreement with the transition $(11,570 \mathrm{yr} \mathrm{BP})$ dated by tree ring chronologies (30), but the transition in the Gulf of Aden record occurs later in all iterations (median $=10,850 \mathrm{yr} \mathrm{BP})$.

The observed offsets in the Tanganyika and Aden $\delta \mathrm{D}_{\text {wax }}$ data across the $\mathrm{H} 1$ and YD terminations respectively could reflect meaningful local climatic deviations; however, as these millennial-scale events are remotely forced by North Atlantic processes, it seems more likely that they reflect unconstrained changes in site radiocarbon $\left({ }^{14} \mathrm{C}\right)$ reservoirs. Lake Tanganyika has a substantial ${ }^{14} \mathrm{C}$ reservoir today (ca. 1000 years) due to its meromixis (22), and while the evolution of this reservoir is constrained by paired bulk organic matter and terrestrial plant macrofossil dates from the LGM to present (22), no data are available for H1, during which time the lake was stratified (31). Likewise, we lack sufficient information to constrain how the Gulf of Aden ${ }^{14} \mathrm{C}$ reservoir has evolved through time. Although our site sits outside of the upwelling zone, it is still likely that the regional radiocarbon reservoir was modulated by the intensity of Arabian Sea upwelling, especially during the deglaciation when large changes are known to have occurred and, at least in the eastern Arabian Sea, shifted the ${ }^{14} \mathrm{C}$ reservoir (32).

In contrast to the deglacial transitions, our analysis suggests that the termination of the AHP is likely synchronous between all three sites $\left(\chi^{2}\right.$ test $p=0.25)$. As the mid-Holocene is less likely to be affected by unknown uncertainties in the ${ }^{14} \mathrm{C}$ reservoir $(22,32)$, we have more confidence that the inferred synchronicity is meaningful. Employing Gaussian error reduction, the average timing of the AHP termination from these three East African sites is $4,960 \pm 70$ year BP $(2 \sigma)$. This is similar to the revised AHP termination estimate from west Africa of 4,900 $\pm 400(2 \sigma)$ and likely synchronous ( $T$-test $p=0.77$ ).

The observed durations of the identified transitions vary from centuries to millennia (Fig. 4); however, sedimentary factors (sedimentation rates and bioturbation) as well as the sampling rate of the proxy influence how the duration is expressed and attenuated in the time series. As evidence of this, we observe a strong relationship between the duration of the transition and proxy sampling interval $(\Delta T ; r=0.95, p=0.0005)$ (fig. S2). Normalizing the duration distributions by this sedimentation effect, we arrive at "theoretical" durations representing the most probable duration given a hypothetical infinite sampling rate (Fig. 4). We find that the calculated theoretical durations are short - occurring within centuries - and broadly similar between sites (Fig. 4). The theoretical duration of the termination of the AHP in our Gulf of Aden record ranges from 280 to 490 years. This duration is in accord with a recent analysis of lake level changes in Lake Turkana in northern Kenya: detailed radiocarbon dating of exposed paleoshoreline horizons revealed that the water level in Lake Turkana dropped permanently by about $50 \mathrm{~m}$ within a few centuries at $5270 \pm 300 \mathrm{yr}$ BP (33) (also synchronous with our analyzed timing; $T$-test $p=0.46$ ). Taken together with our new data from the Gulf of Aden, this suggests that the termination of the AHP was abrupt across a relatively large sector of northeast Africa.

We recognize, however, that there is heterogeneity in terms of the timing and abruptness of the AHP termination across Africa according to the currently available proxy data. Although low-resolution $(N=29$; mean $\Delta T=470$ years), a $\delta \mathrm{D}_{\text {wax }}$ record from Lake Victoria has been interpreted as reflecting a gradual termination of the AHP (34). Farther to the west, a $\delta \mathrm{D}_{w a x}$ record that integrates the Congo drainage basin also shows a gradual termination (10), as does a record of the oxygen isotopic composition of seawater from the Gulf of Guinea (11). Likewise, to the north of our study site, $\delta^{18} \mathrm{O}$ data measured on a Oman stalagmite from Qunf Cave (Fig. 1) suggests a gradual reduction in precipitation across the Arabian Peninsula (19). Collectively, these data suggest that abrupt behavior is not a universal feature across Africa, and may be restricted to the western Sahara and East Africa.

If this is so, then the feedback mechanisms leading to the observed abrupt shifts may be relatively specific to these regions. In the Sahara and Sahel region, the non-linear change in rainfall associated with the termination of the AHP likely involves vegetation feedbacks, which enhance the orbitally-driven response by changing surface albedo and soil moisture $(35,36)$. In contrast, vegetation feedbacks are not likely to have occurred within the humid central African zone, where proxy data suggest that vegetation has not shifted substantially (10). This may explain the lack of abrupt response in that region. Vegetation feedbacks are also hypothesized to be weaker in the eastern Saharan region due to regional differences in vegetation and soil moisture $(3,4,15)$. In the extreme case, the Arabian Peninsula may not have acquired enough vegetation in the Early Holocene to promote a feedback in spite of more pluvial conditions; limited pollen data suggest a predominance of steppe and grassland but no development of shrubland or dry woodland $(1,37)$. It is not clear whether vegetation feedbacks universally contributed to the abrupt shifts in East African hydroclimate. Carbon isotopes measured on the same leaf waxes at the sites analyzed here suggest that a vegetation feedback is plausible at Lake Tanganyika, which experienced a dramatic shift from a mixed humid woodland to a more open shrubland (fig. S3). However, there was relatively little shift in the vegetation near Lake Challa and in the Horn of Africa (fig. S3), suggesting that, as with the Arabian Peninsula, a vegetation-driven feedback is unlikely in arid East Africa.

Alternatively, we hypothesize that non-linear behavior in East African rainfall, including the termination of the AHP, reflects convection feedbacks associated with Indian Ocean sea-surface temperatures (SSTs). This mechanism may explain the difference between the northeast African region and southern Oman. SSTs in the western Indian Ocean hover near the lower bound of the threshold for deep convection $\left(26-28^{\circ} \mathrm{C}\right)$ and their relationship with deep convection is non-linear $(38)$. Therefore, very small changes in western Indian Ocean SSTs - such as those that occur during Indian Ocean Dipole or El Niño events as well as oscillations on the multidecadal timescale - can alter the Walker Circulation in the Indian Ocean and induce anomalous deep convection and heavy rainfall in East Africa $(39,40)$. Rainfall over the southern Arabian Peninsula, though susceptible to such variability (41), primarily falls from July through August in association with the Indian summer monsoon and the influence of the latter likely dominates on orbital timescales $(19,21)$. Therefore, whereas the gradual trend in the Qunf Cave speleothem record represents the direct response of Arabian hydroclimate to the orbitally-driven waning of the boreal summer Indian monsoon, the abrupt shift in East Africa conceivably reflects a convective feedback with a different seasonal dimension. Model simulations suggest that, during the Early Holocene, the northward migration of the summer monsoon winds in response to orbital forcing decreased latent heat flux out of the western Indian Ocean, leading to warmer SSTs during the following September-November ("short") rainy season, a reduced east-west SST gradient, and enhanced convection and rainfall 
over East Africa $(18,42)$. As the winds migrated south during the Holocene in response to orbital forcing, a critical SST threshold may have been crossed, causing an abrupt cessation of deep convection during the short rainy season and regional aridity. Existing proxy data from the Arabian Sea indicate that Early Holocene SSTs were similar to, or perhaps slightly warmer than, present-day SSTs $(43,44)$. Meanwhile, eastern Indian Ocean temperatures were slightly cooler (45) suggesting a reduced east-west temperature gradient that may have facilitated enhanced convection over East Africa, in agreement with the modeling results. It is unclear, however, whether these proxy data are reflecting a change in SSTs during a particular season.

While further research is needed to investigate the role of Indian Ocean SSTs, the $\delta \mathrm{D}_{\text {wax }}$ data presented here suggest that the hydroclimate of East Africa can rapidly shift from dry and wet conditions. More generally, the Gulf of Aden $\delta \mathrm{D}_{\text {wax }}$ record provides a new benchmark of hydroclimatic history for the understudied Horn of Africa region. This study revises our understanding of Holocene climate change in northeast Africa, providing firm evidence that the abrupt termination of the AHP is not limited to the western Sahara. Although the forcings driving the abrupt shifts seen in the paleorecord since the LGM are large and not directly analogous to climate changes experienced today, the possibility of rapid changes in rainfall on human-relevant timescales (centuries) deserves further attention. Paleoclimate data from the last millennium suggest that easternmost Africa was much wetter than present only 300 years ago (40), attesting to the dynamic nature of the hydrological cycle in this region. Identifying the mechanisms driving these dramatic and rapid shifts in East African hydroclimate would greatly improve our understanding of the region's climatology, as well as future predictions of food and water security.

\section{References and Notes}

1. D. Jolly, I. C. Prentice, R. Bonnefille, A. Ballouche, M. Bengo, P. Brenac, G. Buchet, D. Burney, J.-P. Cazet, R. Cheddadi, T. Edorh, H. Elenga, S. Elmoutaki, J. Guiot, F. Laarif, H. Lamb, A.-M. Lezine, J. Maley, M. Mbenza, O. Peyron, M. Reille, I. Reynaud-Farrera, G. Riollet, J. C. Ritchie, E. Roche, L. Scott, I. Ssemmanda, H. Straka, M. Umer, E. Van Campo, S. Vilimumbalo, A. Vincens, M. Waller, Biome reconstruction from pollen and plant macrofossil data for Africa and the Arabian peninsula at 0 and 6000 years. $J$. Biogeogr. 25, 1007-1027 (1998). doi:10.1046/j.1365-2699.1998.00238.x

2. A.-M. Lézine, C. He'ly, C. Grenier, P. Braconnot, G. Krinner, Sahara and Sahel vulnerability to climate changes, lessons from Holocene hydrological data. Quat. Sci. Rev. 30, 3001-3012 (2011). doi:10.1016/j.quascirev.2011.07.006

3. V. Brovkin, M. Claussen, V. Petoukhov, A. Ganopolski, On the stability of the atmosphere-vegetation system in the Sahara/Sahel region. J. Geophys. Res. 103, (D24), 31613 (1998). doi:10.1029/1998JD200006

4. M. Claussen, C. Kubatzki, V. Brovkin, A. Ganopolski, P. Hoelzmann, H.-J. Pachur, Simulation of an abrupt change in Saharan vegetation in the MidHolocene. Geophys. Res. Lett. 26, 2037-2040 (1999). doi:10.1029/1999GL900494

5. P. Hoelzmann, B. Keding, H. Berke, S. Kro"pelin, H.-J. Kruse, Environmental change and archaeology: lake evolution and human occupation in the Eastern Sahara during the Holocene. Palaeogeogr. Palaeoclimatol. Palaeoecol. 169 , 193-217 (2001). doi:10.1016/S0031-0182(01)00211-5

6. R. Kuper, S. Kröpelin, Climate-controlled Holocene occupation in the Sahara: motor of Africa's evolution. Science 313, 803-807 (2006). doi:10.1126/science.1130989 Medline

7. J. E. Kutzbach, B. L. Otto-Bliesner, The Sensitivity of the African-Asian Monsoonal Climate to Orbital Parameter Changes for 9000 Years B.P. in a Low-Resolution General Circulation Model. J. Atmos. Sci. 39, 1177-1188 (1982). doi:10.1175/1520-0469(1982)039<1177:TSOTAA $>2.0$. CO;2

8. M. Claussen, V. Gayler, The Greening of the Sahara during the Mid-Holocene: Results of an Interactive Atmosphere-Biome Model. Global Ecol. Biogeo. Lett. 6, 369-377 (1997). doi:10.2307/2997337

9. P. B. deMenocal, J. Ortiz, T. Guilderson, J. Adkins, M. Sarnthein, L. Baker, M. Yarusinsky, Abrupt onset and termination of the African Humid Period. Quat.
Sci. Rev. 19, 347-361 (2000). doi:10.1016/S0277-3791(99)00081-5

10. E. Schefuß, S. Schouten, R. R. Schneider, Climatic controls on central African hydrology during the past 20,000 years. Nature 437, 1003-1006 (2005). doi:10.1038/nature03945 Medline

11. S. Weldeab, D. W. Lea, R. R. Schneider, N. Andersen, 155,000 years of West African monsoon and ocean thermal evolution. Science 316, 1303-1307 (2007). doi:10.1126/science.1140461 Medline

12. S. Kröpelin, D. Verschuren, A. M. Lézine, H. Eggermont, C. Cocquyt, P. Francus, J. P. Cazet, M. Fagot, B. Rumes, J. M. Russell, F. Darius, D. J. Conley, M. Schuster, H. von Suchodoletz, D. R. Engstrom, Climate-driven ecosystem succession in the Sahara: the past 6000 years. Science 320, 765768 (2008). doi:10.1126/science.1154913 Medline

13. P. Francus, H. von Suchodoletz, M. Dietze, R. V. Donner, F. Bouchard, A.-J. Roy, M. Fagot, D. Verschuren, S. Kröpelin, Varved sediments of Lake Yoa (Ounianga Kebir, Chad) reveal progressive drying of the Sahara during the last 6100 years. Sedimentology 60, 911-934 (2013). doi:10.1111/j.13653091.2012.01370.x

14. J. A. Holmes, Ecology. How the Sahara became dry. Science 320, 752-753 (2008). doi:10.1126/science.1158105 Medline

15. V. Brovkin, M. Claussen, Comment on "Climate-driven ecosystem succession in the Sahara: the past 6000 years". Science 322, 1326b (2008). doi:10.1126/science.1163381 Medline

16. S. Bathiany, M. Claussen, K. Fraedrich, Implications of climate variability for the detection of multiple equilibria and for rapid transitions in the atmospherevegetation system. Clim. Dyn. 38, 1775-1790 (2012). doi:10.1007/s00382$011-1037-\mathrm{x}$

17. F. A. Street-Perrott, D. S. Marchand, N. Roberts, S. P. Harrison, U.S. Department of Energy Technical Report 46, Washington, DC 20545 (1989).

18. J. E. Tierney, S. C. Lewis, B. I. Cook, A. N. LeGrande, G. A. Schmidt, Model, proxy and isotopic perspectives on the East African Humid Period. Earth Planet. Sci. Lett. 307, 103-112 (2011). doi:10.1016/j.epsl.2011.04.038

19. D. Fleitmann, S. J. Burns, M. Mudelsee, U. Neff, J. Kramers, A. Mangini, A. Matter, Holocene forcing of the Indian monsoon recorded in a stalagmite from southern Oman. Science 300, 1737-1739 (2003). doi:10.1126/science. 1083130 Medline

20. S. Jung, G. Davies, G. Ganssen, D. Kroon, Stepwise Holocene aridification in NE Africa deduced from dust-borne radiogenic isotope records. Earth Planet. Sci. Lett. 221, $27-37$ (2004). doi:10.1016/S0012-821X(04)00095-0

21. D. Fleitmann, S. J. Burns, A. Mangini, M. Mudelsee, J. Kramers, I. Villa, U. Neff, A. A. Al-Subbary, A. Buettner, D. Hippler, A. Matter, Holocene ITCZ and Indian monsoon dynamics recorded in stalagmites from Oman and Yemen (Socotra). Quat. Sci. Rev. 26, 170-188 (2007). doi:10.1016/j.quascirev.2006.04.012

22. J. E. Tierney, J. M. Russell, Y. Huang, J. S. Damsté, E. C. Hopmans, A. S. Cohen, Northern hemisphere controls on tropical southeast African climate during the past 60,000 years. Science 322, 252-255 (2008). doi:10.1126/science.1160485 Medline

23. F. Pausata, D. Battisti, K. Nisancioglu, C. Bitz, Chinese stalagmite $\delta 180$ controlled by changes in the Indian monsoon during a simulated Heinrich event. Nat. Geosci. 4, 474-480 (2011). doi:10.1038/ngeo1169

24. J. Slingo, H. Spencer, B. Hoskins, P. Berrisford, E. Black, The meteorology of the Western Indian Ocean, and the influence of the East African Highlands. Philos. Trans. A Math. Phys. Eng. Sci. 363, 25-42 (2005). doi:10.1098/rsta.2004.1473 Medline

25. J. C. Stager, D. B. Ryves, B. M. Chase, F. S. Pausata, Catastrophic drought in the Afro-Asian monsoon region during Heinrich event 1. Science 331, 1299 1302 (2011). doi:10.1126/science.1198322 Medline

26. J. E. Tierney, J. M. Russell, J. S. Sinninghe Damste', Y. Huang, D. Verschuren, Late Quaternary behavior of the East African monsoon and the importance of the Congo Air Boundary. Quat. Sci. Rev. 30, 798-807 (2011). doi:10.1016/j.quascirev.2011.01.017

27. K. J. Anchukaitis, J. E. Tierney, Identifying coherent spatiotemporal modes in time-uncertain proxy paleoclimate records. Clim. Dyn. 41, 1291-1306 (2013). doi:10.1007/s00382-012-1483-0

28. A. Long, B. Rippeteau, Testing Contemporaneity and Averaging Radiocarbon Dates. Am. Antiq. 39, 205 (1974). doi:10.2307/279583

29. K. A. Hughen, T. I. Eglinton, L. Xu, M. C. Makou, Abrupt tropical vegetation response to rapid climate changes. Science 304, 1955-1959 (2004) doi:10.1126/science.1092995 Medline 
30. M. Friedrich, B. Kromer, M. Spurk, J. Hofmann, K. Felix Kaiser, Paleoenvironment and radiocarbon calibration as derived from Lateglacial/Early Holocene tree-ring chronologies. Quat. Int. 61, 27-39 (1999). doi:10.1016/S1040-6182(99)00015-4

31. J. E. Tierney, J. M. Russell, Abrupt climate change in southeast tropical Africa influenced by Indian monsoon variability and ITCZ migration. Geophys. Res. Lett. 34, L15709 (2007). doi:10.1029/2007GL029508

32. M. Staubwasser, F. Sirocko, P. M. Grootes, H. Erlenkeuser, South Asian monsoon climate change and radiocarbon in the Arabian Sea during early and middle Holocene. Paleoceanography 17, 15-1-15-2 (2002). doi:10.1029/2000PA000608

33. Y. Garcin, D. Melnick, M. R. Strecker, D. Olago, J.-J. Tiercelin, East African mid-Holocene wet-dry transition recorded in palaeo-shorelines of Lake Turkana, northern Kenya Rift. Earth Planet. Sci. Lett. 331, 322-334 (2012). doi:10.1016/i.epsl.2012.03.016

34. M. A. Berke, T. C. Johnson, J. P. Werne, K. Grice, S. Schouten, J. S. Sinninghe Damsté, Molecular records of climate variability and vegetation response since the Late Pleistocene in the Lake Victoria basin, East Africa. Quat. Sci. Rev. 55, 59-74 (2012). doi:10.1016/j.quascirev.2012.08.014

35. J. G. Charney, Dynamics of deserts and drought in the Sahel. $Q . J . R$. Meteorol. Soc. 101, 193-202 (1975). doi:10.1002/qj.49710142802

36. J. Shukla, Y. Mintz, Influence of Land-Surface Evapotranspiration on the Earth's Climate. Science 215, 1498-1501 (1982). doi:10.1126/science.215.4539.1498 Medline

37. A. Parker, L. Eckersley, M. M. Smith, A. S. Goudie, S. Stokes, S. Ward, K. White, M. J. Hodson, Holocene vegetation dynamics in the northeastern Rub' al-Khali desert, Arabian Peninsula: a phytolith, pollen and carbon isotope study. J. Quaternary Sci. 19, 665-676 (2004). doi:10.1002/jqs.880

38. C. Zhang, Large-Scale Variability of Atmospheric Deep Convection in Relation to Sea Surface Temperature in the Tropics. J. Clim. 6, 1898-1913 (1993). doi:10.1175/1520-0442(1993)006<1898:LSVOAD>2.0.CO;2

39. E. Black, J. Slingo, K. R. Sperber, An Observational Study of the Relationship between Excessively Strong Short Rains in Coastal East Africa and Indian Ocean SST. Mon. Weather Rev. 131, 74-94 (2003). doi:10.1175/15200493(2003) $131<0074$ :AOSOTR $>2.0 . C O ; 2$

40. J. E. Tierney, J. E. Smerdon, K. J. Anchukaitis, R. Seager, Multidecadal variability in East African hydroclimate controlled by the Indian Ocean. Nature 493, 389-392 (2013). doi:10.1038/nature11785 Medline

41. A. Chakraborty, S. K. Behera, M. Mujumdar, R. Ohba, T. Yamagata, Diagnosis of Tropospheric Moisture over Saudi Arabia and Influences of IOD and ENSO. Mon. Weather Rev. 134, 598-617 (2006). doi:10.1175/MWR3085.1

42. Y. Zhao, P. Braconnot, O. Marti, S. P. Harrison, C. Hewitt, A. Kitoh, Z. Liu, U. Mikolajewicz, B. Otto-Bliesner, S. L. Weber, A multi-model analysis of the role of the ocean on the African and Indian monsoon during the midHolocene. Clim. Dyn. 25, 777-800 (2005). doi:10.1007/s00382-005-0075-7

43. F. Rostek, E. Bard, L. Beaufort, C. Sonzogni, G. Ganssen, Sea surface temperature and productivity records for the past $240 \mathrm{kyr}$ in the Arabian Sea. Deep Sea Res. Part II Top. Stud. Oceanogr. 44, 1461-1480 (1997). doi:10.1016/S0967-0645(97)00008-8

44. P. Anand, D. Kroon, A. D. Singh, R. S. Ganeshram, G. Ganssen, H Elderfield, Coupled sea surface temperature-seawater $\delta{ }^{18} \mathrm{O}$ reconstructions in the Arabian Sea at the millennial scale for the last $35 \mathrm{ka}$. Paleoceanography 23, PA4207 (2008). doi:10.1029/2007PA001564

45. M. Mohtadi, S. Steinke, A. Lückge, J. Groeneveld, E. Hathorne, Glacial to Holocene surface hydrography of the tropical eastern Indian Ocean. Earth Planet. Sci. Lett. 292, 89-97 (2010). doi:10.1016/j.epsl.2010.01.024

46. E. Kalnay, M. Kanamitsu, R. Kistler, W. Collins, D. Deaven, L. Gandin, M. Iredell, S. Saha, G. White, J. Woollen, Y. Zhu, A. Leetmaa, R. Reynolds, M. Chelliah, W. Ebisuzaki, W. Higgins, J. Janowiak, K. C. Mo, C. Ropelewski, J. Wang, R. Jenne, D. Joseph, The NCEP/NCAR 40-Year Reanalysis Project. Bull. Am. Meteorol. Soc. 77, 437-471 (1996). doi:10.1175/15200477(1996)077<0437:TNYRP>2.0.CO;2

Acknowledgments: This study was supported by National Science Foundation grant OCE-1203892 to J. Tierney, NOAA award NAO80AR4320912 to P. deMenocal, and the Lamont-Doherty Earth Observatory Climate and Life Initiative. We thank E. Hamilton and C. Johnson for assistance with the stable isotope measurements; J.-B. Stuut, G. Ganssen and C. Cleroux for assistance with core sampling; J. Fang and T. Guilderson for assistance with the radiocarbon dating; and $\mathrm{C}$. Ummenhofer for comments on the initial versions of the manuscript. We thank the Captain and crew of the $R / V$ Pelagia for their remarkable professionalism during the penultimate leg (Cruise 178; AprilMay, 2001) of the scientific circumnavigation of the African continent. With co-Chief scientist G. Ganssen we were able to obtain valuable samples from this remote and geopolitically challenging region.

\section{Supplementary Materials}

www.sciencemag.org/content/full/science.1240411/DC1

Materials and Methods

Figs. S1 to S3

Tables S1 and S2

References

13 May 2013; accepted 26 September 2013

Published online 10 October 2013

$10.1126 /$ science. 1240411 


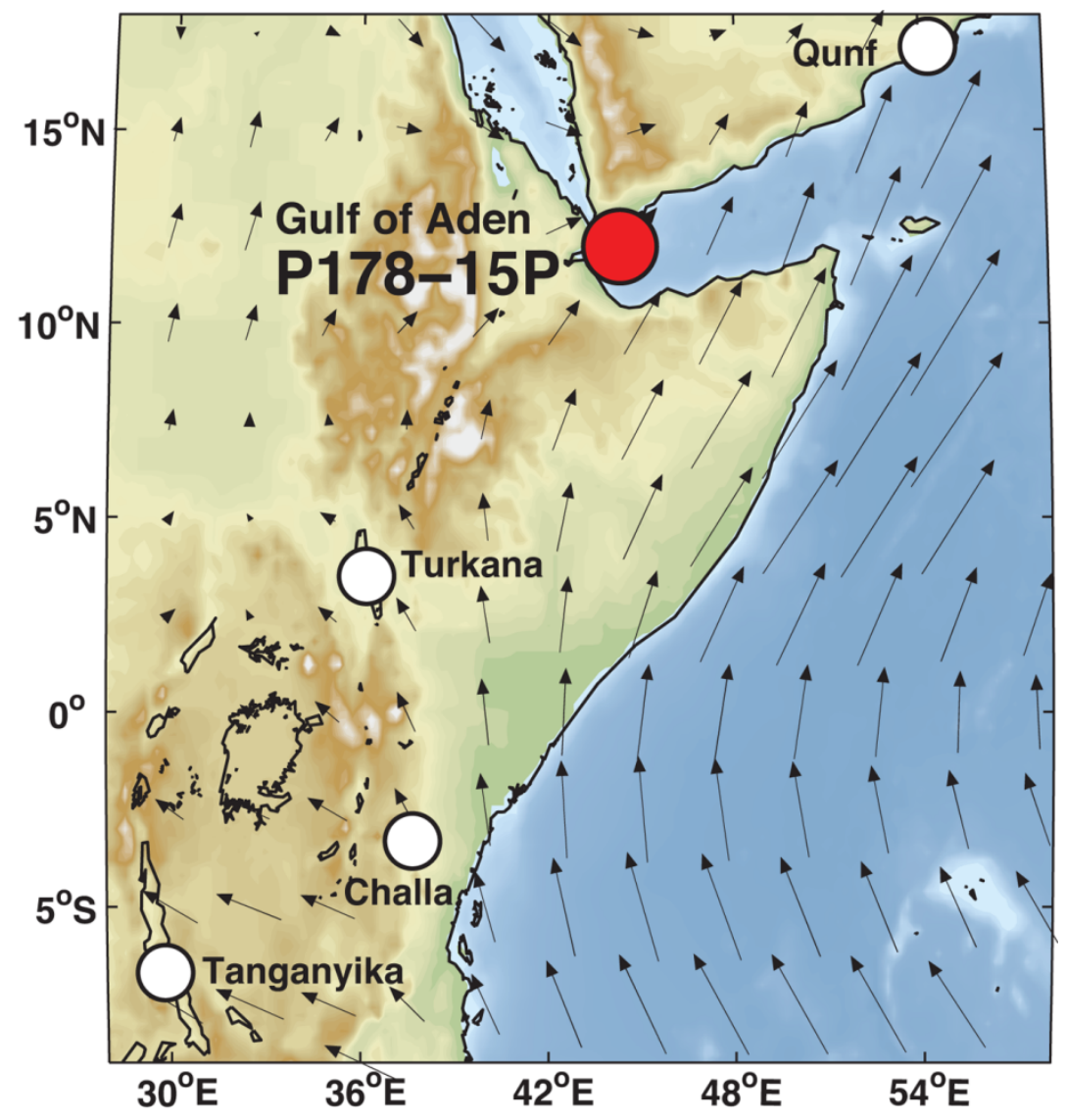

Fig. 1. A map of East Africa, including topography, wind climatology for June-JulyAugust (46), the location of the study site (Gulf of Aden P178-15P; $11^{\circ} 57.3^{\prime} \mathrm{N}, 44^{\circ} 18^{\prime} \mathrm{E}, 869$ $\mathrm{m}$ water depth) and other sites mentioned in the text.

Fig. 2. $\delta D_{\text {wax }}$ data (Ipermil vs. VSMOW) from Gulf of Aden core P178-15P. Black line denotes median values, with the effect of changing ice volume on the isotopic values removed to isolate the regional hydroclimatic component (see Supplementary Information). Gray line shows the $\delta D_{\text {wax }}$ data uncorrected for ice volume changes. Shadings indicate empirical $68 \%$ and $95 \%$ uncertainty bounds (including both analytical- and timeuncertainty) calculated via a Monte Carlo method (27). Red triangles denote the stratigraphic locations of radiocarbon dates. $\mathrm{H} 1$ = Heinrich Event 1, B/A = Bölling-Allerød period, $Y D=$ Younger Dryas, $A H P=$ African Humid Period.

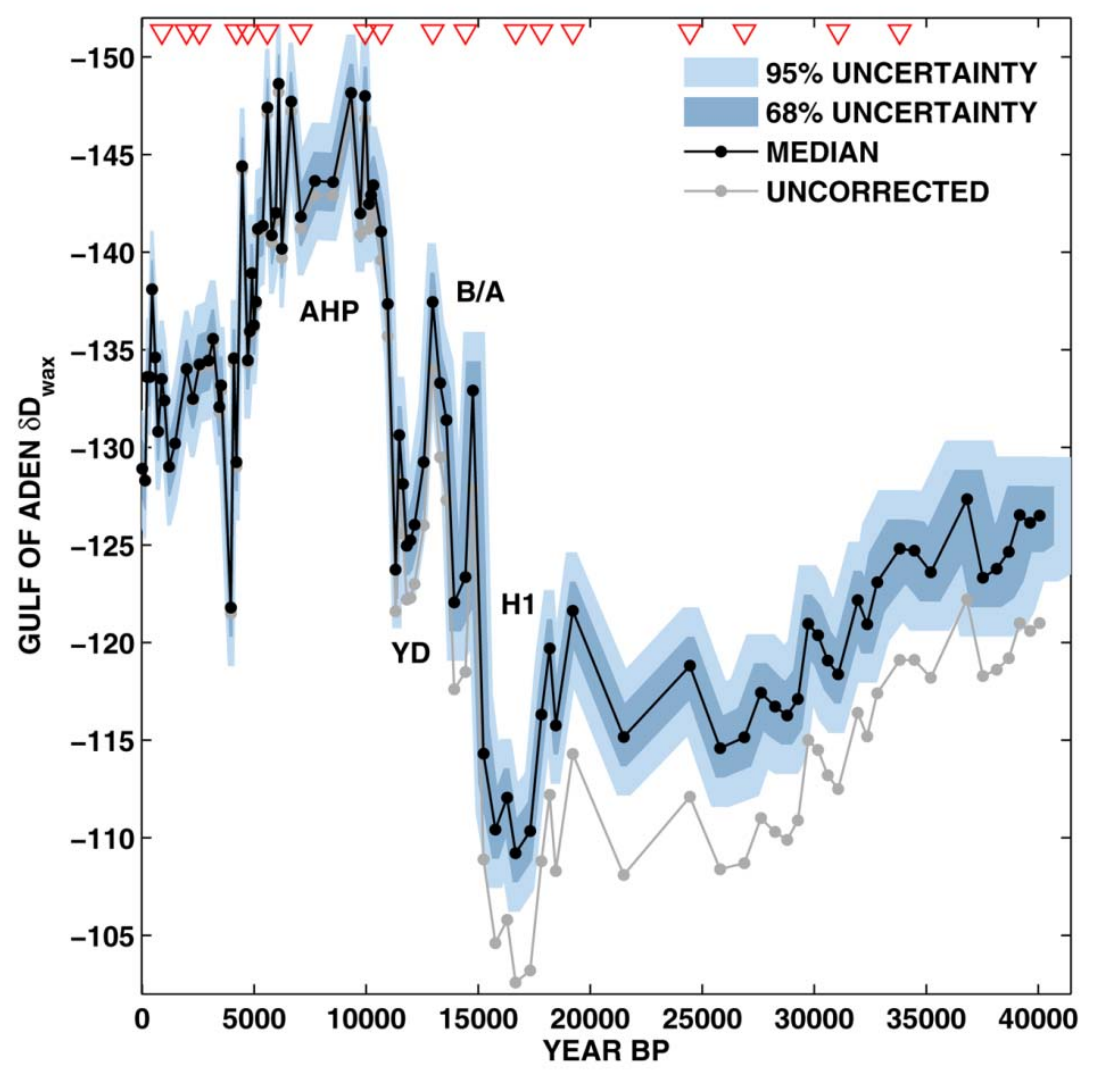




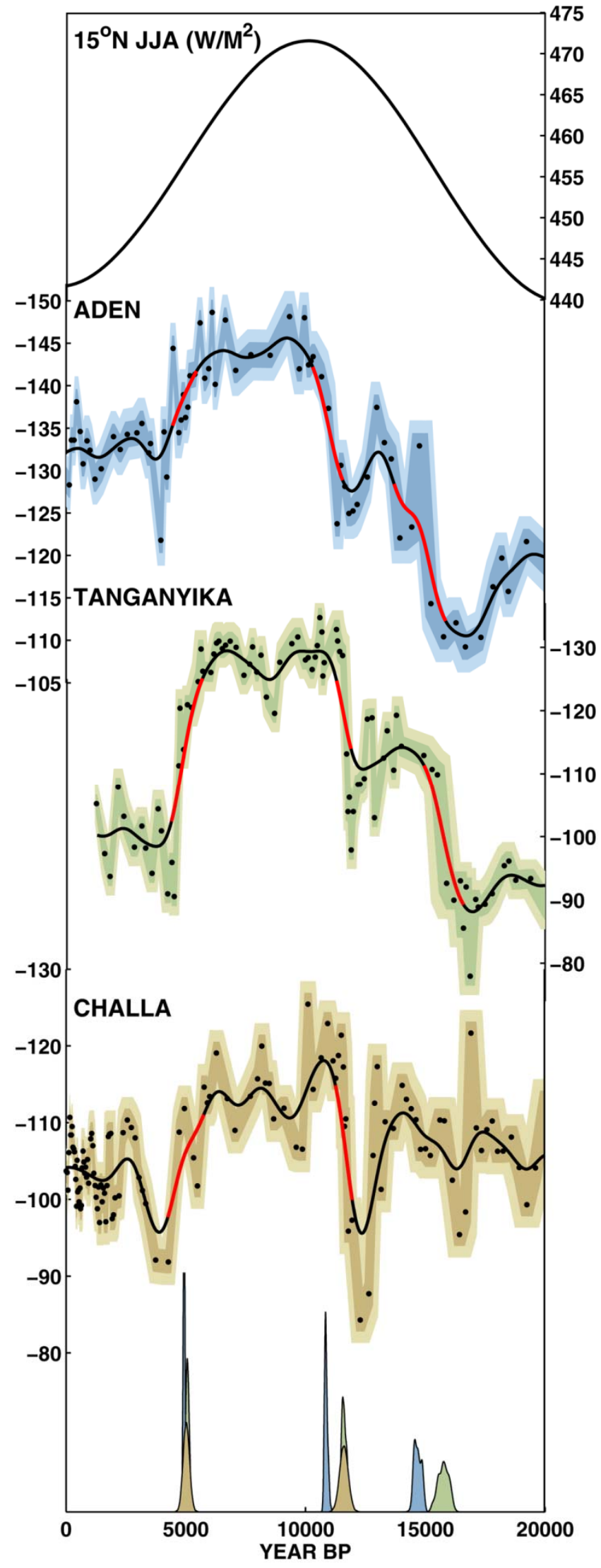

Fig. 3. June-July-August (JJA) insolation $\left(\mathrm{W} / \mathrm{m}^{2}\right)$ at $15^{\circ} \mathrm{N}$, $\delta D_{\text {wax }}$ data (lpermil vs. VSMOW) from three sites in East Africa, and the timing of their abrupt transitions. The effect of changing ice volume on the isotopic values has been removed to isolate the regional hydroclimatic component (see Supplementary Information). Black markers denote median values, shadings indicate empirical $68 \%$ and $95 \%$ uncertainty bounds (including both analytical- and timeuncertainty) calculated via a Monte Carlo method (27). Black line indicates the 2000-yr Gaussian smoothed timeseries for each site, with the identified transitions highlighted in red. Probability distributions (at bottom) represent the timing of each highlighted transition given the dating uncertainties. Note that Lake Challa $\delta D_{\text {wax }}$ does not indicate a large drying associated with Heinrich Event 1 and therefore lacks a $\mathrm{H} 1$ B/A transition (see Supplementary Information). 

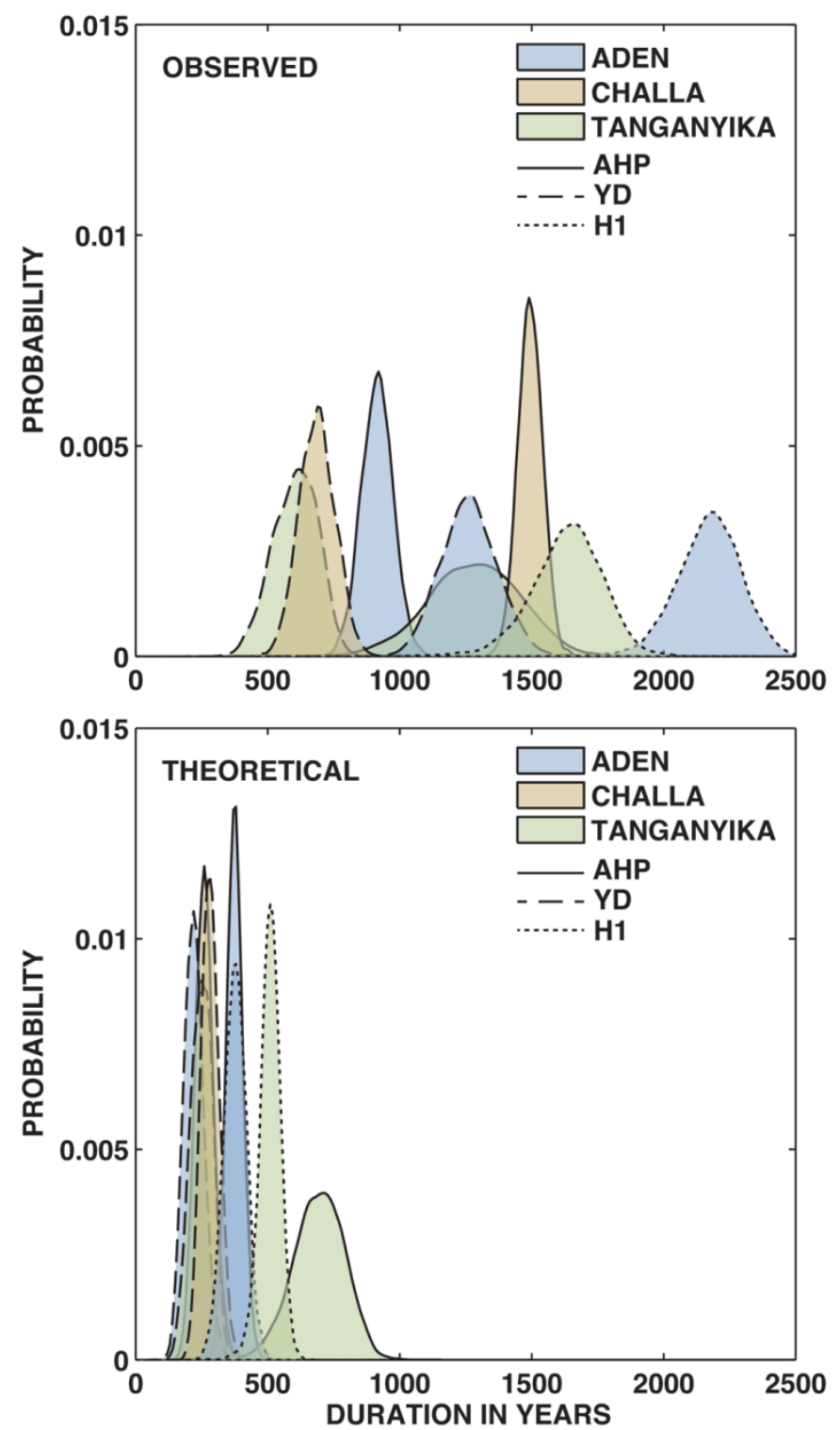

Fig. 4. Observed and theoretical (corrected for the sampling interval effect; see Supplementary Information) probability distributions for the duration of the Heinrich $1(\mathrm{H} 1)$, Younger Dryas (YD) and African Humid Period (AHP) terminations at each East African site. 